\title{
Refractive Index and Its Dispersion of $\mathrm{Na}_{2} \mathrm{O}-\mathrm{GeO}_{2}$ Glasses
}

\author{
Takayuki MITO, Hiromichi TAKEBE* and Kenji MORINAGA* \\ Graduate School, Kyushu University, 6-1, Kasugakouen, Kasuga-shi, Fukuoka 816 \\ *Department of Materials Science and Technology, Graduate School of Engineering Sciences, Kyushu University, \\ 6-1, Kasugakouen, Kasuga-shi, Fukuoka 816
}

\section{$\mathrm{Na}_{2} \mathrm{O}-\mathrm{GeO}_{2}$ 系ガラスの屈折率と分散 三戸貴之・武部博倫* $\cdot$ 森永健次*}

九州大学大学院, 816 春日市春日公園 6-1

*九州大学大学院総合理工学研究科材料開発工学専攻, 816 春日市春日公園 6-1

[Received March 13, 1995; Accepted June 16, 1995]

\begin{abstract}
Accurate refractive indexes of $\mathrm{Na}_{2} \mathrm{O}-\mathrm{GeO}_{2}$ glasses containing $5-30 \mathrm{~mol} \% \mathrm{Na}_{2} \mathrm{O}$ were measured in the wavelength range of 0.334 to $1.710 \mu \mathrm{m}$ using the minimum deviation method. The influence of glass structure on the refractive index and its dispersion has been discussed in terms of the number of the oxygen ion in a unit volume and the apparent refractivity of the oxygen ion. With the addition of $\mathrm{Na}_{2} \mathrm{O}$, the refractive index $n_{d}$ increased at $5<\mathrm{Na}_{2} \mathrm{O}<15 \mathrm{~mol} \%$, showed a maximum around $15 \mathrm{~mol} \% \mathrm{Na}_{2} \mathrm{O}$, and decreased with further addition. The Abbe number $v_{\mathrm{d}}$ decreased monotonically. The variations of $n_{d}$ and $v_{d}$ with $\mathrm{Na}_{2} \mathrm{O}$ content were related to the oxygen coordination number of Ge ions.
\end{abstract}

Key-words : Germanate glass, Refractive index, Dispersion, Number of the oxygen ion, Apparent refractivity of the oxygen ion, Oxygen coordination number

\section{Introduction}

For alkali germanate glasses, the existence of maxima in the variations of refractive index and density with alkali oxide content is well-known. For example, a maximum appears at $15-16 \mathrm{~mol} \% \mathrm{Na}_{2} \mathrm{O}$ in $\mathrm{Na}_{2} \mathrm{O}-\mathrm{GeO}_{2}$ glasses. ${ }^{1), 2)}$ This phenomenon is socalled "germanate anomaly" being also observable for several physical properties such as the third-order non-linearity, ${ }^{3)}$ molar refractivity, ${ }^{4)}$ elastic constant, ${ }^{5)}$, viscosity ${ }^{6)}$ and thermal expansion. ${ }^{7)}$ It has been explained as being due to the variation of oxygen coordination number of $\mathrm{Ge}$ ions between fourfold and six-fold. The identification of four-fold $\mathrm{Ge}$ ions as well as six-fold $\mathrm{Ge}$ ions has been corroborated by Raman scattering,8) X-ray diffraction,9),10) neutron diffraction ${ }^{11)}$ and X-ray emission spectroscopy. ${ }^{12)}$ These measurements may conclude for $\mathrm{Na}_{2} \mathrm{O}-\mathrm{GeO}_{2}$ glasses that the fraction of six-fold $\mathrm{Ge}$ ions increases with the addition of $\mathrm{Na}_{2} \mathrm{O}$, shows a maximum of $20-25 \%$ at about $15-20 \mathrm{~mol} \% \mathrm{Na}_{2} \mathrm{O}$, and then decreases to zero around $35 \mathrm{~mol} \% \mathrm{Na}_{2} \mathrm{O}$. Some researchers also reported that non-bridging oxygen ions were produced above $15-20 \mathrm{~mol} \%$ $\mathrm{Na}_{2} \mathrm{O}$. 8),9),13)

Borate glasses also show anomalous dependences of properties on composition such as molar refractivity, ${ }^{14)}$ refractive index dispersion, ${ }^{14)}$ and apparent refractivity of the oxygen ion. ${ }^{15)}$ Although there are a large number of studies of the properties such as the refractive index and its dispersion for borate glasses, a few papers ${ }^{1), 2), 4)}$ have dealt with those of germanate glasses.

In this work we measured accurate refractive indexes for $\mathrm{Na}_{2} \mathrm{O}-\mathrm{GeO}_{2}$ glasses in the wavelength from 0.334 to $1.710 \mu \mathrm{m}$ using the minimum deviation method. We discuss the influence of change in glass structure on refractive index and its dispersion in terms of the refractivity and the number of the ion in a unit volume for each glass component and compare with the previous results of $\mathrm{BaO}-\mathrm{B}_{2} \mathrm{O}_{3}{ }^{16)}$ and $\mathrm{Na}_{2} \mathrm{O}-\mathrm{SiO}_{2}{ }^{17)}$ glasses.

\subsection{Glass preparation}

Glasses were prepared using $\mathrm{Na}_{2} \mathrm{CO}_{3}(99.5 \%)$ and $\mathrm{GeO}_{2}(99.999 \%)$ as raw materials. Table 1 shows the glass compositions of $\mathrm{Na}_{2} \mathrm{O}-\mathrm{GeO}_{2}$ glasses. This table also shows the compositions of $\mathrm{BaO}-\mathrm{B}_{2} \mathrm{O}_{3}{ }^{16}$ ) and $\mathrm{Na}_{2} \mathrm{O}-\mathrm{SiO}_{2}{ }^{17)}$ glasses to compare with $\mathrm{Na}_{2} \mathrm{O}-$

Table 1. Compositions of $\mathrm{Na}_{2} \mathrm{O}-\mathrm{GeO}_{2}, \mathrm{BaO}-\mathrm{B}_{2} \mathrm{O}_{3}{ }^{16)}$ and $\mathrm{Na}_{2} \mathrm{O}-$ $\mathrm{SiO}_{2}{ }^{17)}$ Glasses Examined in This Study

\begin{tabular}{|c|c|c|c|c|c|}
\hline \multirow{2}{*}{ Glass systems } & \multicolumn{5}{|c|}{ Composition (mol\%) } \\
\hline & $\mathrm{Na}_{2} \mathrm{O}$ & $\mathrm{BaOC}$ & $\mathrm{GeO}_{2}$ & $\mathrm{~B}_{2} \mathrm{O}_{3}$ & $\mathrm{SiO}_{2}$ \\
\hline $\mathrm{Na}_{2} \mathrm{O}-\mathrm{GeO}_{2}$ & $\begin{array}{r}5 \\
10 \\
15 \\
20 \\
25 \\
30\end{array}$ & & $\begin{array}{l}95 \\
90 \\
85 \\
80 \\
75 \\
70\end{array}$ & & \\
\hline $\mathrm{BaO}-\mathrm{B}_{2} \mathrm{O}_{3}{ }^{16)}$ & & $\begin{array}{l}20 \\
22.5 \\
25 \\
27.5 \\
30 \\
32.5 \\
35 \\
37.5 \\
40\end{array}$ & & $\begin{array}{l}80 \\
77.5 \\
75 \\
72.5 \\
70 \\
67.5 \\
65 \\
62.5 \\
60\end{array}$ & \\
\hline $\mathrm{Na}_{2} \mathrm{O}-\mathrm{SiO}_{2}{ }^{17)}$ & $\begin{array}{r}4.9 \\
9.7 \\
14.5 \\
19.1 \\
24.2 \\
26.7 \\
\end{array}$ & & & & $\begin{array}{l}95.1 \\
90.3 \\
85.5 \\
80.9 \\
75.8 \\
73.3 \\
\end{array}$ \\
\hline
\end{tabular}


$\mathrm{GeO}_{2}$ glasses in latter discussion. Mixed batches of $2.0 \times 10^{-2} \mathrm{~kg}$ for $\mathrm{Na}_{2} \mathrm{O}-\mathrm{GeO}_{2}$ glasses were melted in $\mathrm{Pt}$ crucibles without a lid at $1250-1270^{\circ} \mathrm{C}$ for $2 \mathrm{~h}$ in air. Each glass was poured into a graphite mold heated at the glass transition temperature and subsequently annealed at near the glass transition temperature. Prisms having about $10 \times 20 \mathrm{~mm}$ faces were cut and optically polished in our laboratory.

\subsection{Refractive index and density measure- ments}

Refractive index was measured with a precision spectrometer (Model GMR-1, Kalnew, Nagano, Japan) at $23^{\circ} \mathrm{C}$ in the wavelength range of 0.334 to $1.710 \mu \mathrm{m}$ using $\mathrm{Hg}, \mathrm{Cd}, \mathrm{H}_{2}$ and $\mathrm{He}$ lamps as spectral sources. The errors for the refractive indexes were $1.0 \times 10^{-4}$ at the He d-line, which were dependent on striae in glass samples.

To evaluate the dispersion characteristics, Abbe number $v_{\mathrm{d}}=\left(n_{\mathrm{d}-1}\right) /\left(n_{\mathrm{F}}-n_{\mathrm{C}}\right) \quad$ was determined, ${ }^{18)}$ where $n_{\mathrm{d}}, n_{\mathrm{F}}$, and $n_{\mathrm{C}}$ are the refractive indexes at $0.5876 \mu \mathrm{m}$ (He d-line), $0.4861 \mu \mathrm{m}\left(\mathrm{H}_{2} \mathrm{~F}\right.$-line) and $0.6563 \mu \mathrm{m}\left(\mathrm{H}_{2} \mathrm{C}\right.$-line $)$. This definition concludes that large Abbe number means low dispersion.

Density was determined by the Archimedes method using kerosene as an immersion liquid.

2.3 Ionic refractivity and number of the ion in a unit volume

Refractive index $n$ is given in terms of the density $d$, the average molecular weight $M$, and the molar refractivity $R$ using the Lorentz-Lorenz formula.

$$
\frac{n^{2}-1}{n^{2}+2} \cdot \frac{M}{d}=R
$$

This formula indicates that refractive index is affected by two factors, that is, the packing and polarization of a glass. The number of the ion in a unit volume and the ionic refractivity for each component in a glass were determined to evaluate the packing and the polarization of a glass. In this study we used these parameters to understand the factors affecting refractive index and its dispersion.

The apparent refractivity of the oxygen ion ${ }^{15), 19)}$ was calculated from the ionic refractivities of the cations and the molar refractivity of a glass on the assumption that the ionic refractivities of the cations remain constant with the variation of composition. Table 2 shows the ionic refractivities of the cations quoted from Fajans'19) and Kordes'20) works. The ionic refractivity of $\mathrm{Ge}^{4+}$ was also shown in this table, which was calculated by Verweij and Buster $\left.{ }^{4}\right)$ for the hypothetical case that the germanium glass is structurally equivalent to silica glass and the refractivity of the oxygen ion in the germanate glass is

Table 2. Ionic Refractivities of the Cations Quoted from the Works of Fajans and Kreidl, ${ }^{19)}$ Kordes $^{20)}$ and Verweij and Buster ${ }^{4)}$

\begin{tabular}{ccccc}
\hline $\mathrm{Na}^{+}$ & $\mathrm{Ba}^{2+}$ & $\mathrm{B}^{3+}$ & $\mathrm{Si}^{4+}$ & $\mathrm{Ge}^{4+}$ \\
\hline 0.47 & 4.73 & 0.05 & 0.12 & 2.6 \\
\hline
\end{tabular}

same as that in silica glass.

The number of the ion in a unit volume for each component in a glass was calculated from the density and the average molecular weight of a glass.

\section{Results}

\subsection{Refractive index and its dispersion}

Figure 1 shows the variation of refractive index with wavelength for $\mathrm{Na}_{2} \mathrm{O}-\mathrm{GeO}_{2}$ glasses. Table 3 shows the refractive indexes relative to the air of $\mathrm{Na}_{2} \mathrm{O}-\mathrm{GeO}_{2}$ glasses at representative wavelengths and their densities. Figure 2 compares (a) refractive index $n_{\mathrm{d}}$ and (b) density results of the present work

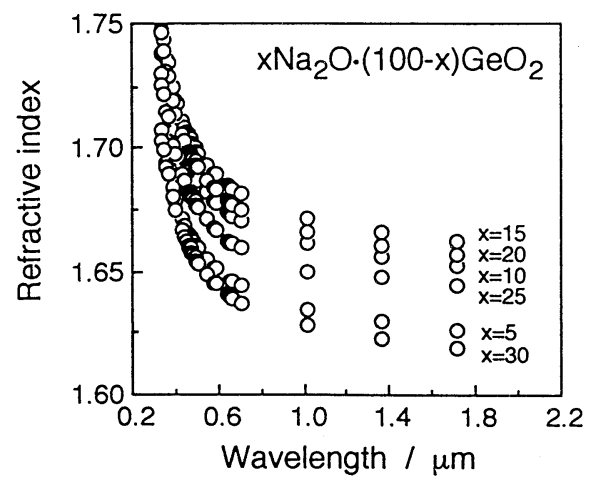

Fig. 1. Refractive index versus wavelength for sodium germanate glasses.

Table 3. Refractive Index Results Relative to the Air of Sodium Germanate Glasses at Representative Wavelengths and Their Densities

\begin{tabular}{|c|c|c|c|c|c|c|c|}
\hline \multirow{2}{*}{$\begin{array}{l}\text { Wavelength } \\
\quad(\mu \mathrm{m})\end{array}$} & \multirow{2}{*}{$\begin{array}{l}\text { Spectral } \\
\text { source }\end{array}$} & \multicolumn{6}{|c|}{ Nominal glass composition (mol\%) } \\
\hline & & $\begin{array}{r}5 \mathrm{Na}_{2} \mathrm{O} \cdot \\
95 \mathrm{GeO}_{2} \\
\end{array}$ & $\begin{array}{c}10 \mathrm{Na}_{2} \mathrm{O} \\
90 \mathrm{GeO}_{2} \\
\end{array}$ & $\begin{array}{c}15 \mathrm{Na}_{2} \mathrm{O} \\
85 \mathrm{GeO}_{2} \\
\end{array}$ & $\begin{array}{c}20 \mathrm{Na}_{2} \mathrm{O} \cdot \\
80 \mathrm{GeO}_{2}\end{array}$ & $\begin{array}{l}25 \mathrm{Na}_{2} \mathrm{O} \\
75 \mathrm{GeO}_{2}\end{array}$ & $\begin{array}{r}30 \mathrm{Na}_{2} \mathrm{O} \cdot \\
70 \mathrm{GeO}_{2} \\
\end{array}$ \\
\hline 0.3650 (i) & $\mathrm{Hg}$ & 1.6924 & 1.7220 & 1.7344 & 1.7292 & 1.7126 & 1.6898 \\
\hline $0.4047(h)$ & $\mathrm{Hg}$ & 1.6790 & 1.7077 & 1.7196 & 1.7139 & 1.6976 & 1.6751 \\
\hline $0.4358(\mathrm{~g})$ & $\mathrm{Hg}$ & 1.6713 & 1.6995 & 1.7111 & 1.7053 & 1.6891 & 1.6669 \\
\hline $0.4800\left(F^{\prime}\right)$ & $\mathrm{Cd}$ & 1.6632 & 1.6909 & 1.7023 & 1.6964 & 1.6802 & 1.6579 \\
\hline $0.4861(F)$ & $\mathrm{H}_{2}$ & 1.6623 & 1.6899 & 1.7012 & 1.6954 & 1.6791 & 1.6567 \\
\hline $0.5461(\mathrm{e})$ & $\mathrm{Hg}$ & 1.6549 & 1.6821 & 1.6931 & 1.6872 & 1.6711 & 1.6489 \\
\hline $0.5876(d)$ & $\mathrm{He}$ & 1.6512 & 1.6781 & 1.6891 & 1.6831 & 1.6670 & 1.6448 \\
\hline $0.6439\left(C^{\prime}\right)$ & ) $\mathrm{Cd}$ & 1.6475 & 1.6739 & 1.6847 & 1.6787 & 1.6626 & 1.6405 \\
\hline $0.6563(\mathrm{C})$ & $\mathrm{H}_{2}$ & 1.6465 & 1.6731 & 1.6839 & 1.6780 & 1.6618 & 1.6397 \\
\hline $0.7065(r)$ & $\mathrm{He}$ & 1.6445 & 1.6704 & 1.6812 & 1.6752 & 1.6593 & 1.6370 \\
\hline $1.0140(t)$ & $\mathrm{Hg}$ & 1.6344 & 1.6610 & 1.6712 & 1.6658 & 1.6495 & 1.6277 \\
\hline \multicolumn{2}{|c|}{ Density $/ 10^{3} \mathrm{~kg} \cdot \mathrm{m}^{-3}$} & 3.89 & 4.03 & 4.07 & 4.01 & 3.89 & 3.72 \\
\hline
\end{tabular}
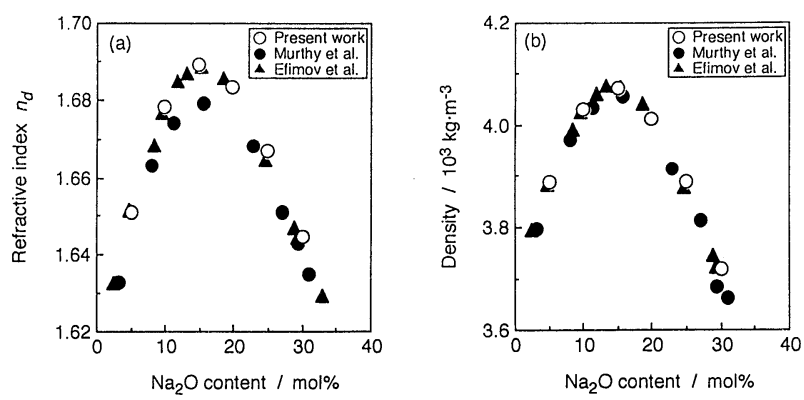

Fig. 2. (a) Refractive index $n_{\mathrm{d}}$ and (b) density versus $\mathrm{Na}_{2} \mathrm{O}$ content for sodium germanate glasses. $\bigcirc$ Present work, Murthy and Ip, ${ }^{1)} \boldsymbol{\Delta}$ Efimov et al. ${ }^{2)}$ 


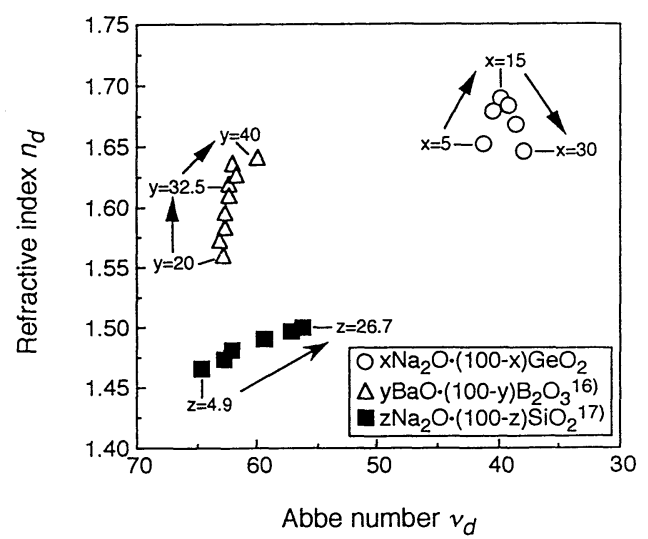

Fig. 3. Refractive index $n_{\mathrm{d}}$ versus Abbe number $v_{\mathrm{d}}$ for sodium germanate, barium borate, ${ }^{16)}$ and sodium silicate glasses ${ }^{17)}: \bigcirc$ $\mathrm{Na}_{2} \mathrm{O}-\mathrm{GeO}_{2}, \triangle \mathrm{BaO}-\mathrm{B}_{2} \mathrm{O}_{3}{ }^{16)}$ and $\mathbf{N a} \mathrm{Na}_{2} \mathrm{O}-\mathrm{SiO}_{2}{ }^{17)}$ glasses.

with those of Murthy and $\mathrm{Ip}^{1)}$ and Efimov et al. ${ }^{2)}$ All the results show a maximum at about 15-16 mol\% $\mathrm{Na}_{2} \mathrm{O}$ in each figure.

Figure 3 shows the relationship between the refractive index $n_{\mathrm{d}}$ and Abbe number $v_{\mathrm{d}}$ for $\mathrm{Na}_{2} \mathrm{O}-$ $\mathrm{GeO}_{2}$ glasses. The results of $\mathrm{BaO}-\mathrm{B}_{2} \mathrm{O}_{3}$ and $\mathrm{Na}_{2} \mathrm{O}-$ $\mathrm{SiO}_{2}$ glasses are also shown in this figure to compare with those of $\mathrm{Na}_{2} \mathrm{O}-\mathrm{GeO}_{2}$ glasses. For $\mathrm{Na}_{2} \mathrm{O}-\mathrm{SiO}_{2}$ glasses the refractive index $n_{\mathrm{d}}$ increases monotonically with the addition of $\mathrm{Na}_{2} \mathrm{O}$ and Abbe number $v_{d}$ decreases largely.

There is a distinct difference between the results of $\mathrm{Na}_{2} \mathrm{O}-\mathrm{SiO}_{2}$ glasses and those of $\mathrm{BaO}-\mathrm{B}_{2} \mathrm{O}_{3}$ and $\mathrm{Na}_{2} \mathrm{O}-\mathrm{GeO}_{2}$ glasses. For $\mathrm{Na}_{2} \mathrm{O}-\mathrm{GeO}_{2}$ glasses the maximum, which means relatively high refractive index and low dispersion, appears around $15 \mathrm{~mol} \%$ $\mathrm{Na}_{2} \mathrm{O}$. In $5<\mathrm{Na}_{2} \mathrm{O}<15 \mathrm{~mol} \%$ in which the oxygen coordination number of $\mathrm{Ge}$ ions varies from 4 to 6 with the addition of $\mathrm{Na}_{2} \mathrm{O},{ }^{8)-12)}$ the refractive index $n_{\mathrm{d}}$ increases with a slight decrease of $v_{\mathrm{d}}$. This behavior is similar to the result of $\mathrm{BaO}-\mathrm{B}_{2} \mathrm{O}_{3}$ glasses in $20<\mathrm{BaO}<32.5 \mathrm{~mol} \%$, in which the oxygen coordination number of $\mathrm{B}$ ions varies from 3 to 4 with the addition of $\mathrm{BaO}{ }^{21)}$ At $\mathrm{Na}_{2} \mathrm{O}>15 \mathrm{~mol} \%$, the refractive index $n_{\mathrm{d}}$ decreases with a slight decrease of $v_{\mathrm{d}}$ in $\mathrm{Na}_{2} \mathrm{O}-\mathrm{GeO}_{2}$ glasses. On the other hand, for $\mathrm{Na}_{2} \mathrm{O}-$ $\mathrm{SiO}_{2}$ glasses, $n_{\mathrm{d}}$ increases with a larger decrease of $v_{\mathrm{d}}$, i.e., a characteristic of high refractive index and high dispersion.

3.2 Number of the ion in a unit volume for each glass component

Figure 4 shows the variations of (a) the number of $\mathrm{O}^{2-}$, (b) the numbers of $\mathrm{Na}^{+}$and $\mathrm{Ba}^{2+}$, and (c) the numbers of $\mathrm{Ge}^{4+}, \mathrm{B}^{3+}$ and $\mathrm{Si}^{4+}$ with modifier content in $\mathrm{Na}_{2} \mathrm{O}-\mathrm{GeO}_{2}, \mathrm{BaO}-\mathrm{B}_{2} \mathrm{O}_{3}$ and $\mathrm{Na}_{2} \mathrm{O}-\mathrm{SiO}_{2}$ glasses. For $\mathrm{Na}_{2} \mathrm{O}-\mathrm{GeO}_{2}$ glasses the number of $\mathrm{O}^{2-}$ in a unit volume increases in $5<\mathrm{Na}_{2} \mathrm{O}<15 \mathrm{~mol} \%$, exhibits a maximum around $15 \mathrm{~mol} \% \mathrm{Na}_{2} \mathrm{O}$, and then decreases at $\mathrm{Na}_{2} \mathrm{O}>15 \mathrm{~mol} \%$ (see Fig. $4(\mathrm{a})$ ). Although this anomaly is also shown around 32.5 $\mathrm{mol} \% \mathrm{BaO}$ for $\mathrm{BaO}-\mathrm{B}_{2} \mathrm{O}_{3}$ glasses in this figure, the number of $\mathrm{O}^{2-}$ in a unit volume decreases monotonically for $\mathrm{Na}_{2} \mathrm{O}-\mathrm{SiO}_{2}$ glasses. The numbers of $\mathrm{Na}^{+}$ and $\mathrm{Ba}^{2+}$ in a unit volume increase largely in proportion to $\mathrm{Na}_{2} \mathrm{O}$ or $\mathrm{BaO}$ contents in all the glass systems (see Fig. 4(b)). The number of $\mathrm{Ge}^{4+}$ in a unit volume increase slightly with the addition of $\mathrm{Na}_{2} \mathrm{O}$ in the range of 5 to $10 \mathrm{~mol} \% \mathrm{Na}_{2} \mathrm{O}$, but as a whole the numbers of $\mathrm{Ge}^{4+}, \mathrm{B}^{3+}$ and $\mathrm{Si}^{4+}$ in a unit volume decrease with the additions of $\mathrm{Na}_{2} \mathrm{O}$ or $\mathrm{BaO}$ in all the glass systems (see Fig. 4(c)).

3.3 Apparent refractivity of the oxygen ion

Figure 5 shows the variations of the apparent refractivity of $\mathrm{O}^{2-}$ with modifier content in $\mathrm{Na}_{2} \mathrm{O}-$

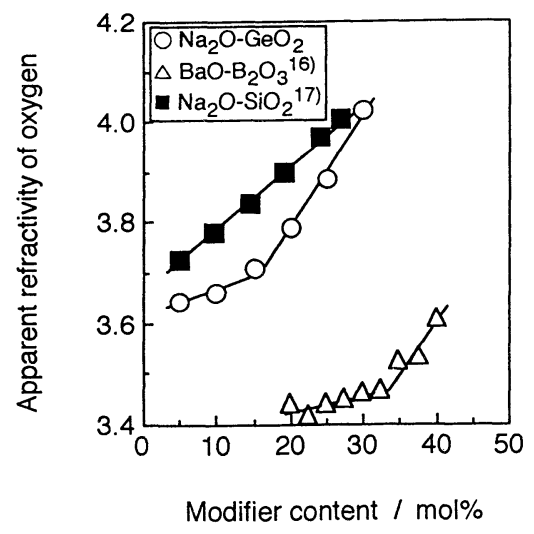

Fig. 5. Apparent refractivity of the oxygen ion versus modifier content for germanate, borate and silicate glasses: $\bigcirc \mathrm{Na}_{2} \mathrm{O}-\mathrm{GeO}_{2}$, $\triangle \mathrm{BaO}-\mathrm{B}_{2} \mathrm{O}_{3}{ }^{16)}$ and $\mathrm{Na}_{2} \mathrm{O}-\mathrm{SiO}_{2}{ }^{17)}$ glasses. Solid lines are guides to the eye.
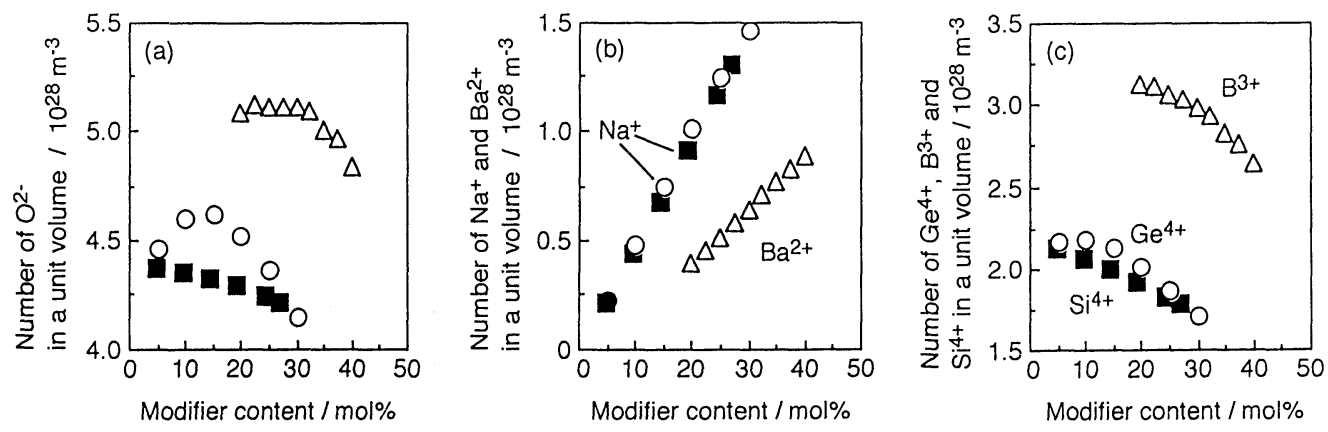

Fig. 4. The numbers of (a) $\mathrm{O}^{2-}$, (b) $\mathrm{Na}^{+}$and $\mathrm{Ba}^{2+}$, and (c) $\mathrm{Ge}^{4+}, \mathrm{B}^{3+}$ and $\mathrm{Si}^{4+}$ in a unit volume versus modifier content for germanate, borate and silicate glasses: $\bigcirc \mathrm{Na}_{2} \mathrm{O}-\mathrm{GeO}_{2}, \triangle \mathrm{BaO}-\mathrm{B}_{2} \mathrm{O}_{3}{ }^{16)}$ and $\mathrm{Na}_{2} \mathrm{O}-\mathrm{SiO}_{2}{ }^{17)}$ glasses. 
$\mathrm{GeO}_{2}, \mathrm{BaO}-\mathrm{B}_{2} \mathrm{O}_{3}$ and $\mathrm{Na}_{2} \mathrm{O}-\mathrm{SiO}_{2}$ glasses. For $\mathrm{Na}_{2} \mathrm{O}-$ $\mathrm{GeO}_{2}$ glasses, the results of the apparent refractivity of $\mathrm{O}^{2-}$ can be plotted as the combination of two lines intersecting around $15 \mathrm{~mol} \% \mathrm{Na}_{2} \mathrm{O}$, and in $5<\mathrm{Na}_{2} \mathrm{O}$ $<15 \mathrm{~mol} \%$ the slope of the line is smaller than that in $15<\mathrm{Na}_{2} \mathrm{O}<30 \mathrm{~mol} \%$. A similar phenomenon is also shown around $32.5 \mathrm{~mol} \% \mathrm{BaO}$ for $\mathrm{BaO}-\mathrm{B}_{2} \mathrm{O}_{3}$ glasses. However, for $\mathrm{Na}_{2} \mathrm{O}-\mathrm{SiO}_{2}$ glasses the apparent refractivity of $\mathrm{O}^{2-}$ increases largely in proportion to $\mathrm{Na}_{2} \mathrm{O}$ content.

\section{Discussion}

The numbers of $\mathrm{Ge}^{4+}, \mathrm{B}^{3+}$ and $\mathrm{Si}^{4+}$ in a unit volume decrease with the additions of $\mathrm{Na}_{2} \mathrm{O}$ or $\mathrm{BaO}$, and the ionic refractivities of them are smaller than that of the oxygen ion. The numbers of $\mathrm{Na}^{+}$and $\mathrm{Ba}^{2+}$ in a unit volume increase monotonically in proportion to $\mathrm{Na}_{2} \mathrm{O}$ or $\mathrm{BaO}$ contents for all the glass systems. However, the number of $\mathrm{O}^{2-}$ in a unit volume shows different variation with composition for each glass system in Figs. 4 and 5. These results suggest that the difference of the relationship between the refractive index $n_{\mathrm{d}}$ and Abbe number $v_{\mathrm{d}}$ for each glass system is due to the difference of the role of the oxygen ion. We argue that the oxygen ion has a large ionic refractivity and show different variation for each glass system.

There are two types of the oxygen ion in a glass, that is, bridging oxygen (BO) and non-bridging oxygen (NBO). Generally, the resonance absorption related to NBO exists at longer wavelengths in the ultraviolet region than that of $\mathrm{BO}{ }^{22)}$ It was also reported that a glass shows a high dispersion characteristic as the average resonance absorption of a glass shifts to longer wavelengths. ${ }^{23), 24)}$ From these studies, glasses with larger numbers of NBO show higher dispersion characteristics.

In the results of $\mathrm{Na}_{2} \mathrm{O}-\mathrm{SiO}_{2}$ glasses shown in Figs. 4 (a) and 5, the number of the oxygen ion in a unit volume decreases and the apparent refractivity of the oxygen ion increases monotonically with the addition of $\mathrm{Na}_{2} \mathrm{O}$. These variations are due to the decrease of the polymerization degree of silicate networks and the formation of NBO. ${ }^{25)}$ Therefore, it can be argued that the increase in the refractive index $n_{\mathrm{d}}$ of $\mathrm{Na}_{2} \mathrm{O}-\mathrm{SiO}_{2}$ glasses is mainly caused by an increase in the apparent refractivity of the oxygen ion with the formation of NBO; the increase of the refractive index $n_{\mathrm{d}}$ accompanies with the large decrease of $v_{\mathrm{d}}$ (relatively high dispersion) (see Fig. $3)$.

On the other hand, in $5<\mathrm{Na}_{2} \mathrm{O}<15 \mathrm{~mol} \%$ of $\mathrm{Na}_{2} \mathrm{O}-\mathrm{GeO}_{2}$ glasses, in which the oxygen coordination number of $\mathrm{Ge}$ ions varies from 4 to $6,{ }^{8)}$-12) the apparent refractivity of the oxygen ion increases slightly and the number of the oxygen ion in a unit volume increases largely with the addition of $\mathrm{Na}_{2} \mathrm{O}$, as shown in Figs. 4 (a) and 5. In this region, $n_{\mathrm{d}}$ increases largely with the slight decrease of $v_{\mathrm{d}}$ (rela- tively low dispersion) to compare with the $\mathrm{Na}_{2} \mathrm{O}$ $\mathrm{SiO}_{2}$ glasses. The increase of $n_{\mathrm{d}}$ is likely to be caused by an increase of the number of the oxygen ion in a unit volume, that is, the packing of BO. This phenomenon is also shown in $20<\mathrm{BaO}<32.5 \mathrm{~mol} \%$ of $\mathrm{BaO}-\mathrm{B}_{2} \mathrm{O}_{3}$ glasses. ${ }^{16)}$ In this region of the borate glasses, the refractive index is mainly affected by the number of $\mathrm{Ba}^{2+}$ in a unit volume, because the $\mathrm{Ba}^{2+}$ ion has a larger ionic refractivity of 4.74 compared with the results of apparent refractivity of the oxygen ion, and the number of the oxygen ion in a unit volume and the apparent refractivity of the oxygen ion are almost constant.

For $\mathrm{Na}_{2} \mathrm{O}-\mathrm{GeO}_{2}$ glasses, while the $n_{\mathrm{d}}$ shows a maximum around $15 \mathrm{~mol} \% \mathrm{Na}_{2} \mathrm{O}$ and then decreases with the addition of $\mathrm{Na}_{2} \mathrm{O}, v_{\mathrm{d}}$ decreases monotonically (see Fig. 3). In $15<\mathrm{Na}_{2} \mathrm{O}<30 \mathrm{~mol} \%$, the decrease in the refractive index $n_{\mathrm{d}}$ is due to a large decrease in the number of the oxygen ion in a unit volume, in spite of an increase in the apparent refractivity of the oxygen ion; the monotonic decrease in Abbe number $v_{\mathrm{d}}$ is due to an increase in the apparent refractivity of the oxygen ion, that is, the formation of NBO.8),9),13)

\section{Conclusions}

The influence of change in glass structure on the refractive index and its dispersion for $\mathrm{Na}_{2} \mathrm{O}-\mathrm{GeO}_{2}$ glasses is discussed in terms of the number of the oxygen ion in a unit volume and the apparent refractivity of the oxygen ion. The apparent refractivity of the oxygen ion is calculated on the assumption that the ionic refractivities of the cations remain constant with composition variation.

(1) In $5<\mathrm{Na}_{2} \mathrm{O}<15 \mathrm{~mol} \%$ of $\mathrm{Na}_{2} \mathrm{O}-\mathrm{GeO}_{2}$ glasses, the increase of $n_{\mathrm{d}}$ is likely to be caused by an increase in the number of the oxygen ion in a unit volume, that is the packing of the bridging oxygen, which is related to the variation of oxygen coordination number of $\mathrm{Ge}$ ions from 4 to 6 with the addition of $\mathrm{Na}_{2} \mathrm{O}$. The refractive index $n_{\mathrm{d}}$ increases with a slight decrease of $v_{\mathrm{d}}$, the result shows relatively high refractive index and low dispersion characteristics around $15 \mathrm{~mol} \% \mathrm{Na}_{2} \mathrm{O}$.

(2) In $15<\mathrm{Na}_{2} \mathrm{O}<30 \mathrm{~mol} \%$ of $\mathrm{Na}_{2} \mathrm{O}-\mathrm{GeO}_{2}$ glasses, $n_{\mathrm{d}}$ decreases with a slight decrease of $v_{\mathrm{d}}$. In this region, the decrease of $n_{\mathrm{d}}$ is mainly caused by an decrease in the number of the oxygen ion in a unit volume. On the other hand, the slight decrease of $v_{\mathrm{d}}$ is mainly caused by an increase in the apparent refractivity of the oxygen ion, in other words, the formation of the non-bridging oxygen.

Acknowledgement One of the authors ( $\mathrm{H}$. Takebe) acknowledges the Nippon Sheet Glass Foundation 1994 for Materials Science.

References

1) M. K. Murthy and J. Ip, Nature, 201, 285-86 (1964).

2) A. M. Efimov, E. K. Mazurina, V. A. Kharyuzov and M. V. Proskuryakov, Fiz. Khim. Stekla, 2, 151-56 (1976). 
3) O. Sugimoto, H. Nasu, J. Matsuoka and K. Kamiya, J. NonCryst. Solids, 161, 118-22 (1993).

4) H. Verweij and J. H. J. M. Buster, J. Mater. Sci., 14, 931-40 (1979).

5) A. Osaka, K. Takahashi and K. Ariyoshi, J. Non-Cryst. Solids, 70, 243-52 (1985).

6) J. E. Shelby, J. Am. Ceram. Soc., 57, 436-39 (1974).

7) J. E. Shelby and J. Ruller, Phys. Chem. Glasses, 28, 262-68 (1987).

8) H. Verweij and J. H. J. M. Buster, J. Non-Cryst. Solids, 34, 81-99 (1979).

9) S. Sakka and K. Kamiya, J. Non-Cryst. Solids, 49, 103-16 (1982).

10) K. Kamiya and S. Sakka, Phys. Chem. Glasses, 20, 60-64 (1979).

11) M. Ueno, M. Misawa and K. Suzuki, Physica, 120B, 347-51 (1983).

12) C. D. Yin, H. Morikawa, F. Marumo, Y. Gohshi, Y. Z. Ba and S. Fukushima, J. Non-Cryst. Solids, 69, 97-103 (1984).

13) B. J. M. Smets and T. P. A. Lommen, J. Non-Cryst. Solids, 46, 21-32 (1981).
14） D. Warner and H. Rawson, J. Non-Cryst. Solids, 29, 231-37 (1978).

15) N. J. Kreidl, Glastech. Ber., 62, 213-18 (1989).

16) T. Mito, S. Fujino, H. Takebe and K. Morinaga, J. Ceram. Soc. Japan, 102, 1163-67 (1994).

17) G. W. Morey and H. E. Merwin, J. Opt. Soc. Am., 22, 63262 (1932)

18) S. H. Wemple, Phys. Rev. B, 7, 3767-77 (1973).

19) K. Fajans and N. J. Kreidl, J. Am. Ceram. Soc., 31, 105-14 (1948).

20) E. Kordes, Glastech. Ber., 17, 67-76 (1939).

21) S. Greenblatt and P. J. Bray, Phys. Chem. Glasses, 8, 190-93 (1967).

22) S. Hirota and T. Izumitani, J. Non-Cryst. Solids, 72, 39-50 (1985).

23) S. Fujino, H. Takebe and K. Morinaga, J. Am. Ceram. Soc., 78, 1179-84 (1995).

24) S. Hirota and T. Izumitani, J. Non-Cryst. Solids, 29, 109-17 (1978).

25) R. Bruckner, H. Ulrich and H. Goretzki, Glastech. Ber., 51, 1-7 (1978). 